\title{
REPORT ON DAY TRIP (5/16/07) TO VISIT MESOZOIC ROCKS EXPOSED IN PORT GRAHAM AND NEAR SELDOVIA, SOUTHERN KENAI PENINSULA
}

by

Robert B. Blodgett ${ }^{1}$

Field work was conducted May 16, 2007. We (Dave LePain, Alaska Division of Geological \& Geophysical Surveys; Rick Stanley, U.S. Geological Survey; and myself) departed on the fourth helicopter load leaving from the Ocean Shores Motel in Homer to examine the Upper Triassic in Port Graham and Lower Jurassic west of Point Naskowhak in Kachemak Bay (see fig. 1 for location of stops visited).

\section{Stop 1 - Blodgett station 07RB01 (=07DL005 LePain station)}

\section{Lat. $59.35529^{\circ} \mathrm{N}$, Long. $151.84725^{\circ} \mathrm{W}$}

Small cove (bight) along southwest side of Port Graham (NE1/4 SE1/4 NE1/4 Sec. 31, T9S, R15W, Seldovia B-5 Quadrangle; fig. 1). Cove has small stream (with waterfall above) flowing into it. I had chosen this cove as this is where the earlier GPS coordinates of Andrew Caruther's and George Stanley's Monotis subcircularis locality (their 04AC41) was indicated. In subsequent conversation, it turns out that their locality was situated in the next cove northwest along the shoreline (probably hundred or so meters away).

The exposures at 07RB01 appear to the highly faulted. The southeastern third of the outcrop consists of volcanic-rich conglomeratic sands with locally abundant limestone clasts (most are small, but are up to $1.8 \mathrm{~m}$ across).

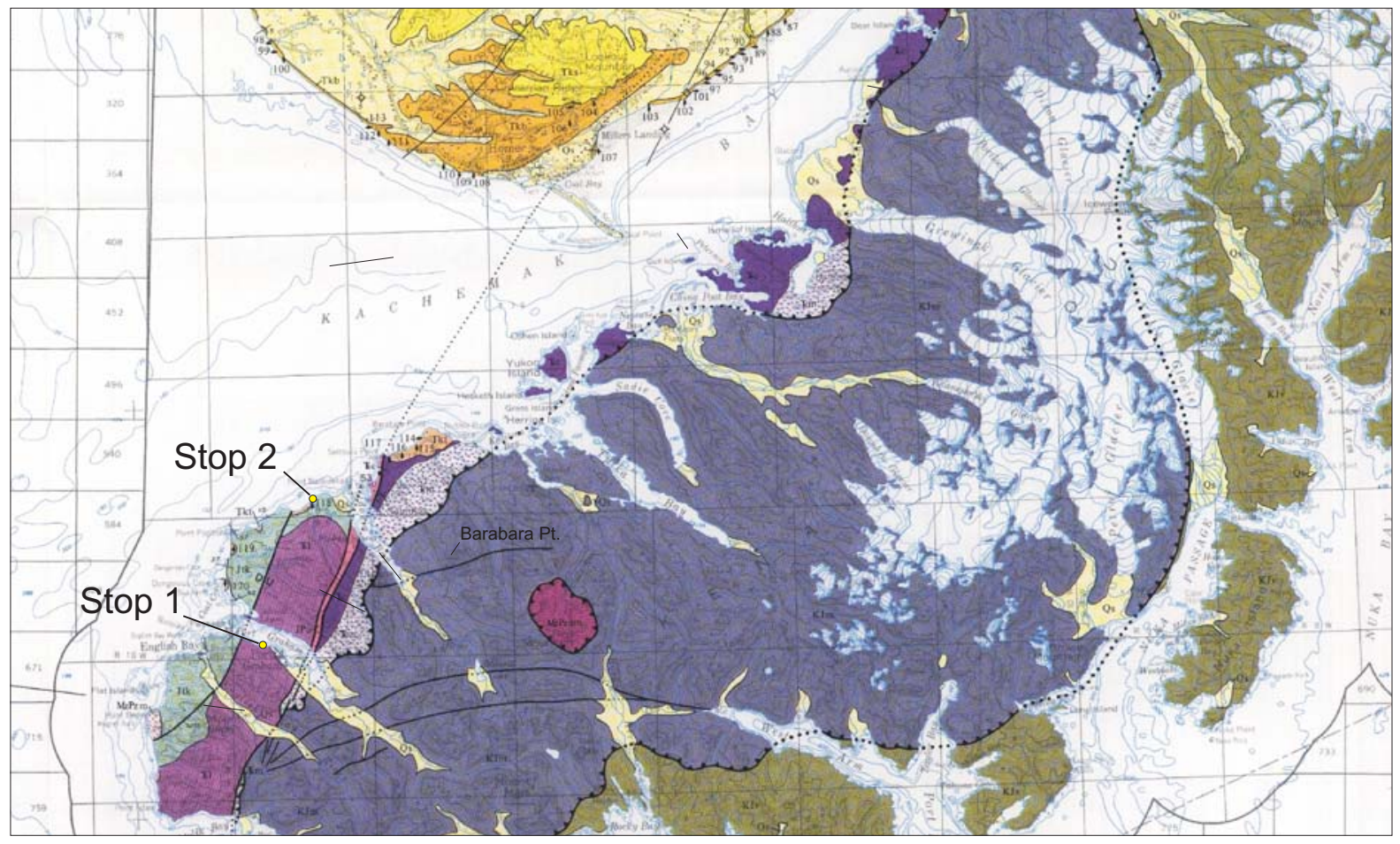

Figure 1 - Map showing two outcrop locations examined on May 16, 2007. Geology from Magoon and others (1976) compilation map. Scale is provided by the 6-mile by 6-mile township-range grid covering on-shore portions of the map. Magoon and others (1976) describe map unit Trl unit is described as Upper Triassic limestone and tuff and unit Jtk as the Lower Jurassic Talkeetna Formation consisting of volcanic breccia, tuff, agglomerate, and aphanitic lava flows. See Bradley and others (1999) for more recent mapping of Mesozoic rocks on the southern Kenai Peninsula.

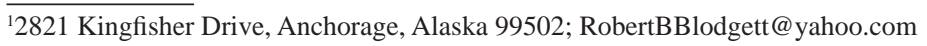


Other clast types, notably volcanic and intrusive? rocks, are present. Conglomerate at the south end weathers green-gray in color. Clasts are angular to subrounded, appear to have been transported, and individual clasts are of various colors. One limestone clast contains a number of recrystallized corals or spongiomorph specimens. We collected a number of lithology samples, and also one conodont sample (07DL005B) that was examined by Andrea Krumhardt (University of Alaska Fairbanks) and found to be barren of conodonts. We observed one mold of a high-spired gastropod reminiscent of the genus Omphaloptychia (see fig. 2). Fossil molds are present here (a few isolated bivalve shells) and in similar rocks on the north side of the cove (in another fault block). These fossils are difficult, if not impossible, to remove. I suggest that any future paleontological work done here include making casts of these molds using latex rubber. A light-green weathering dike is also present at the south end of this exposure.

The central part of the cove (with the stream flowing over it) consists of nearly flat-lying calcareous mudstone/shale with beds ranging from $5 \mathrm{~mm}$ to $5 \mathrm{~cm}$ thick (fig. 3). Beds strike $38^{\circ}$ and dip $14^{\circ}$ to the northwest. No megafossils were observed on bedding planes. The contact between the mudstone/shale section and the southerly adjacent volcanic conglomerate interval is a prominent high-angle fault. The shale beds have a weak drag fold developed in them adjacent to the fault zone.

The northern part of the cove consists of volcanic conglomerate and sandstone similar to that seen at the south end of the cove. Bivalve molds are common here and one resembles Cassianella, suggesting a Late Triassic age. Again, these specimens are difficult to remove, so future work here should include making latex rubber molds of these impressions.

No monotid bivalves were observed here, which were so abundant at Andrew Caruther's nearby locality 04AC41 (see fig. 4). The presence of Monotis subcircularis and Halobia (of the superba species type) in the past was thought to indicate the presence of both Carnian (in the case of Halobia superba) and late Norian (in the case of M. subcircularis). See reports of Martin $(1915,1926)$ and Silberling and others $(1997)$ for previous noted occurrences of these species on both sides of Port Graham. Silberling and others (1997) reexamined the Halobias from older USGS collections at Port Graham and determined them to represent two middle Norian age species, $H$. lineata and $H$. dilitata, rather than $H$. superba. This reassignment indicates that all Upper Triassic fossil collections from this locality can be restricted to the middle and late Norian.

The beds at this locality appear overmature in terms of oil potential.

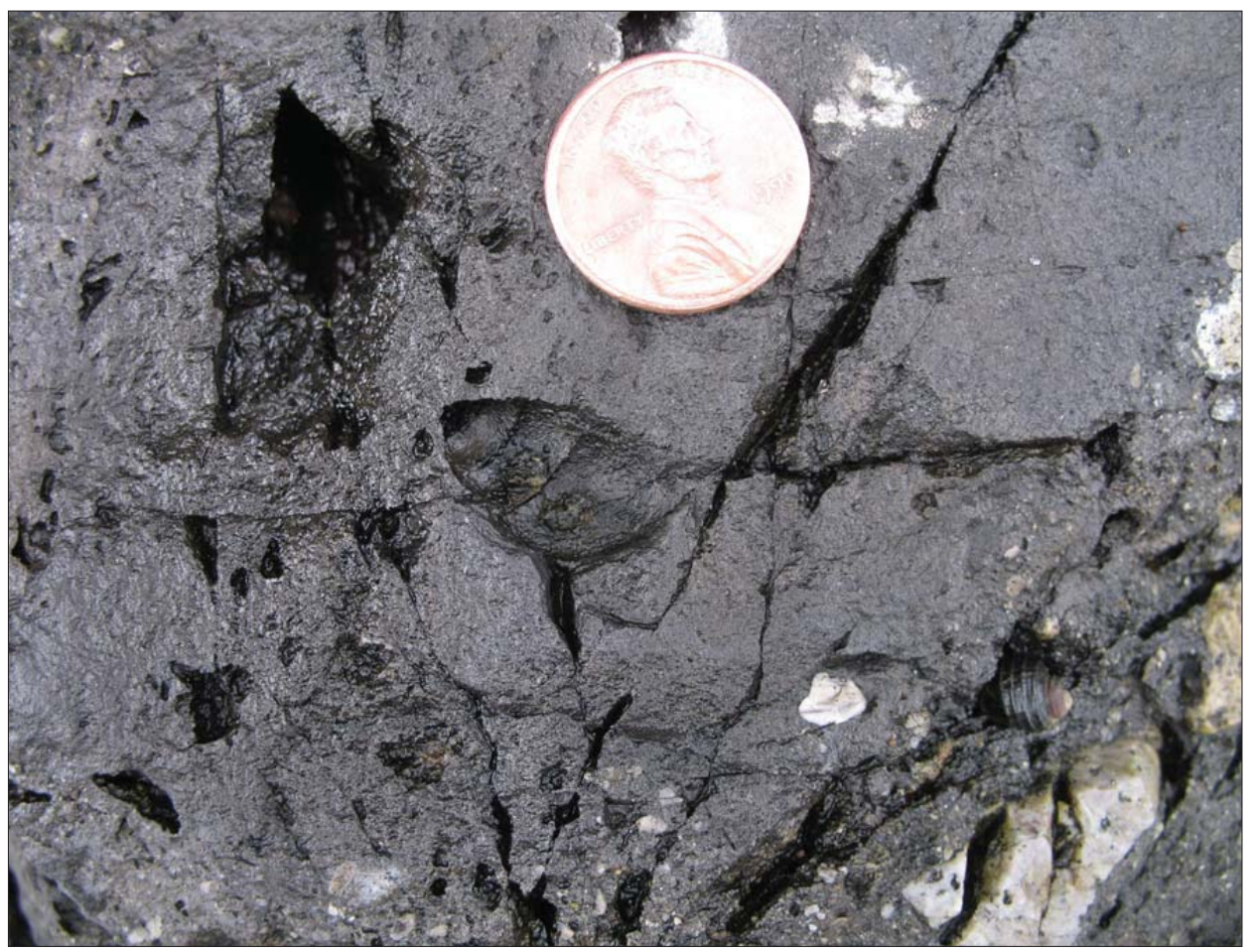

Figure 2. Mold of a high-spired gastropod suggestive of the genus Omphaloptychia (which is rather common in Norian strata of western North America). This specimen was found in the volcanic conglomerate/sandstone interval at the southern end of exposed beds at 07RB01. 


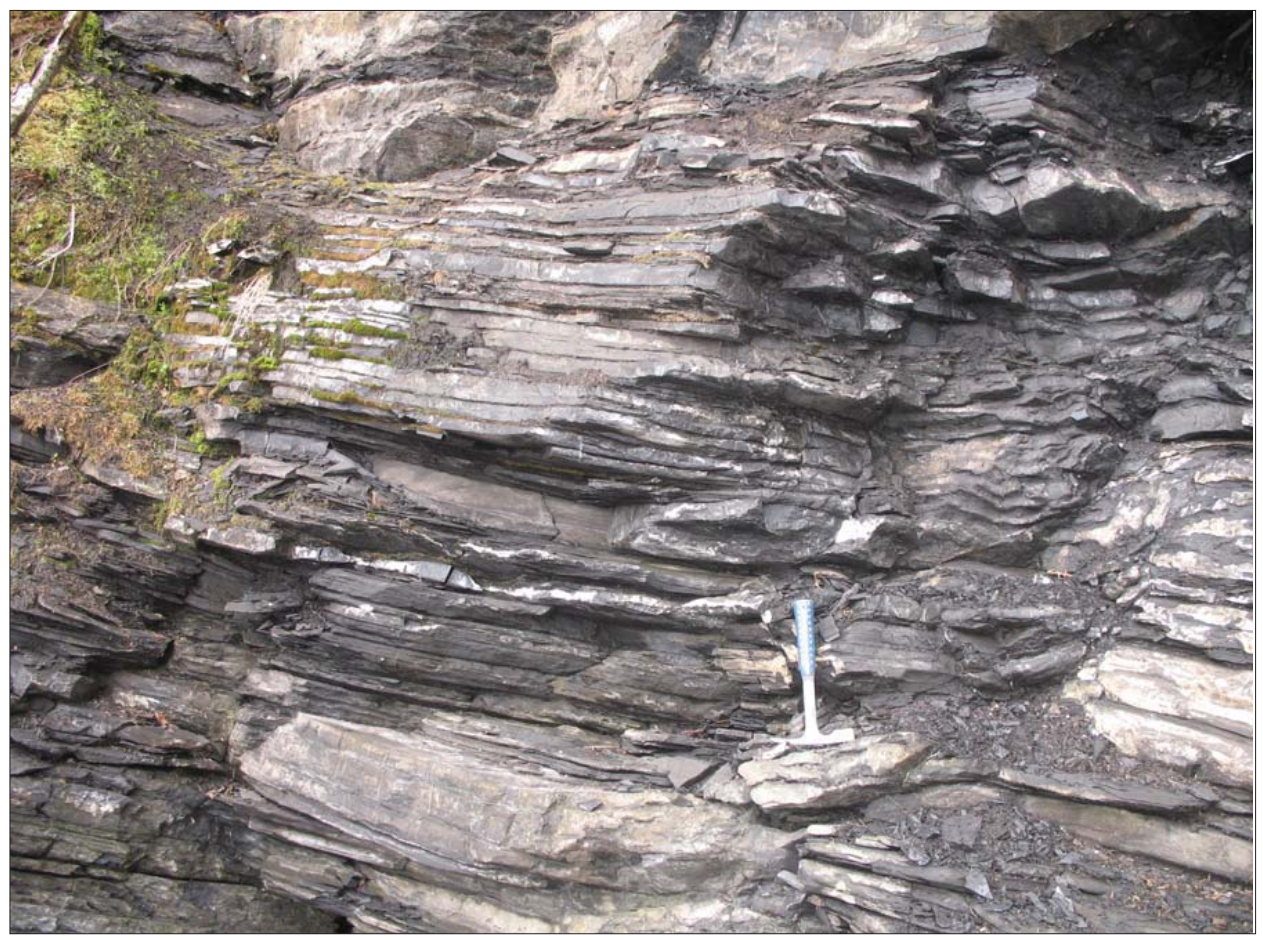

Figure 3. Thin- to medium-bedded shale/mudstone interval that forms central part of exposure of the cove at 07RB01. No visible megafossils observed in the shale.

Figure 4. Photograph showing many specimens of Monotis subcircularis within the folded argillite layers of 04AC41 (visited by Andrew Caruthers, George Stanley, and John Kelley in 2004). My original intent was to visit this locality but Caruthers indicated GPS coordinates were probably off, as it now appears they visited the next cove immediately to the northwest of where we landed by helicopter. Monotis subcircularis is a widespread index bivalve fossil for the early late Norian (late Late Triassic). This species is very widespread in the eastern Panthalassa Ocean and is reported from western North America (both in craton and adjoining accreted terranes),

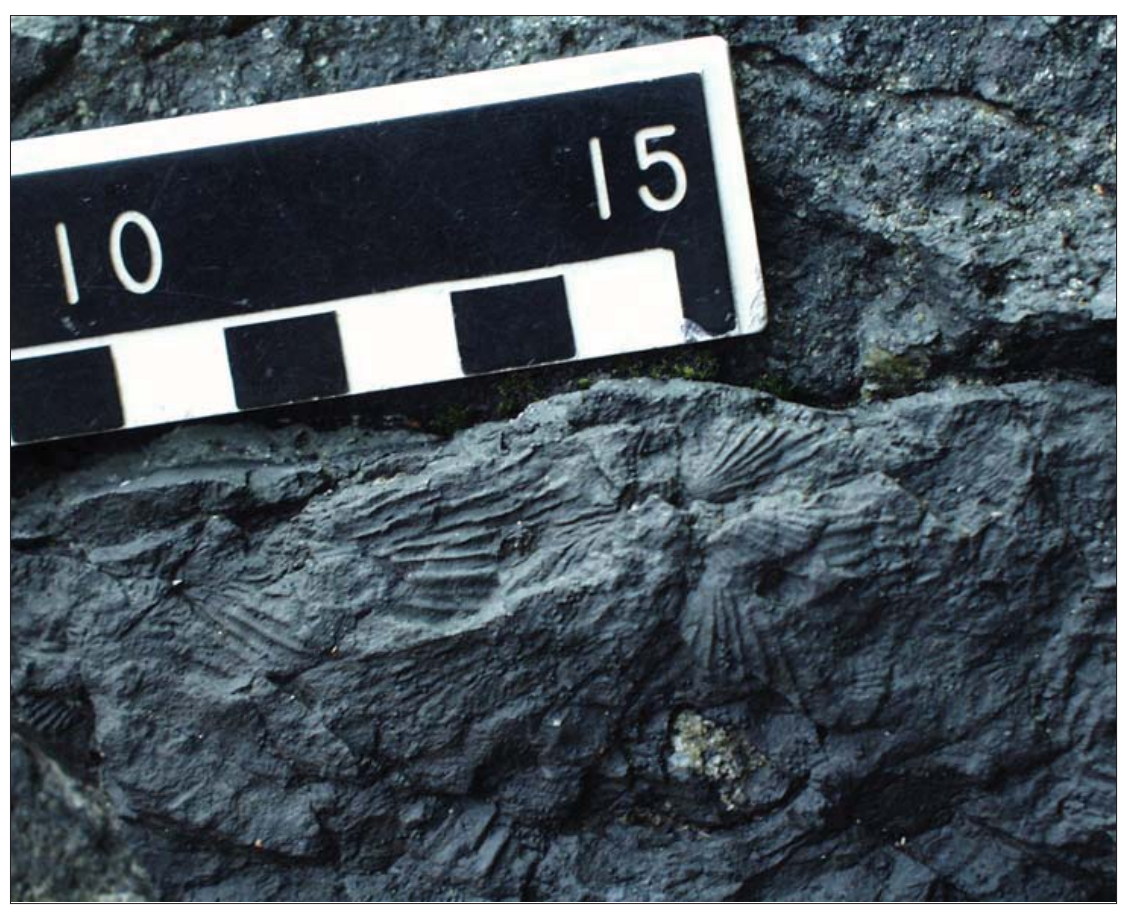
the Canadian Arctic Islands, and Peru. A few occurrences also are now known from eastern Asia (i.e., the Koryak terrane of northeastern Siberia). The monotaxic mass accumulations of this species probably indicate outer shelf depths, below wave-base, in anoxic or dysaerobic conditions. This same species is also extremely abundant and dominates near the entire Norian-age section of Kamishak Formation exposed at Puale Bay on the Alaska Peninsula. The species has previously been reported from Port Graham by Martin $(1915,1926)$ and Silberling and others (1997). 


\section{Stop 2 - Blodgett stations 07RB02 and 07RB03}

Two stations made in Lower Jurassic volcaniclastic rocks that lie immediately east of Tertiary Kenai Group exposures (LePain station 06DL022) along beach approximately $2.9 \mathrm{~km}$ west-southwest of Point Naskowhak (NE1/4 NE1/4 Sec. 35, T9S, R15W, Seldovia B-5 Quadrangle; fig. 1). Tertiary rocks appear to fill a canyon that eroded into underlying Lower Jurassic succession. The lowermost exposed part of the Lower Jurassic section is composed of volcanic flow rock with coarse crystalline fabrics (abundant glass). Most of the Jurassic section is composed of dark greenish-gray weathering coarse volcaniclastic sandstone with mudstone interbeds and conglomeratic lenses. Exposed section is at least $20 \mathrm{~m}$ thick. Fossils are abundant at this section, mostly belonging to the bivalve genus Weyla (indicative of an Early Jurassic age). A few other undetermined bivalve species are present as well as a few undetermined high-spired gastropods. Ammonites collected here indicate an early Sinemurian (Early Jurassic) age (Imlay, 1981). Hettangian-age ammonites were also recognized at nearby localities by Imlay (1981). Martin $(1915,1926)$ provides antiquated faunal lists for this section.

\section{RB02}

Lat. $59.44346^{\circ} \mathrm{N}$, Long. $151.78622^{\circ} \mathrm{W}$

Near the base of sedimentary portion of Jurassic section (west of prominent head; see fig. 5 for outcrop photo). Dave LePain notes that sedimentary structures indicate some down-slope transport here. Numerous specimens of the bivalve Weyla are found here (figs. 6-7), probably representing the species Weyla alata (von Buch, 1838). Many of these are in growth position, suggesting that although the host beds are transported, they have not been displaced great distances. Beds strike $\mathrm{N} 70^{\circ} \mathrm{E}$ and dip $50^{\circ}$ toward the northwest.

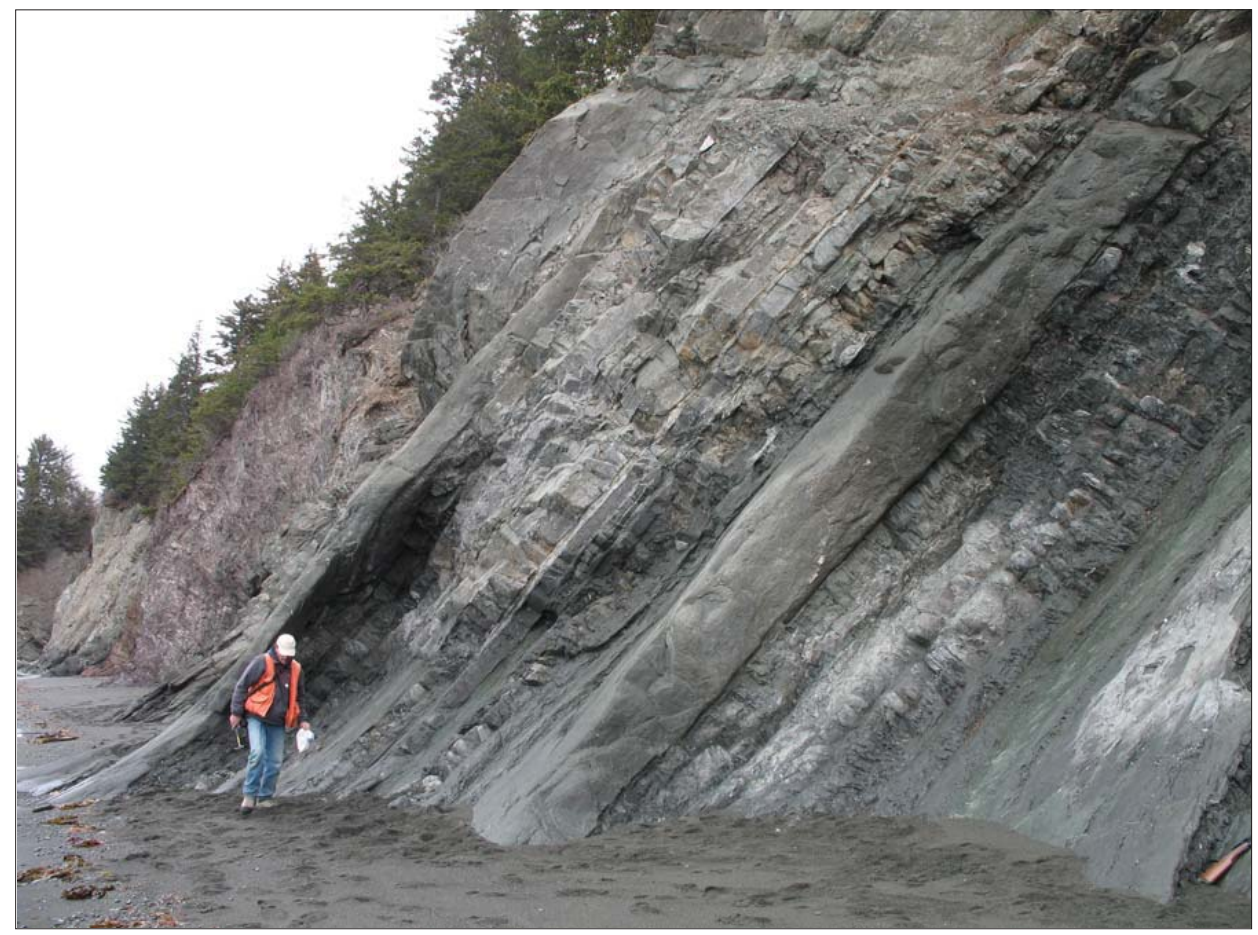

Figure 5. View looking northeast (upsection) from near base of exposed Lower Jurassic section at locality $07 R B 02$. 


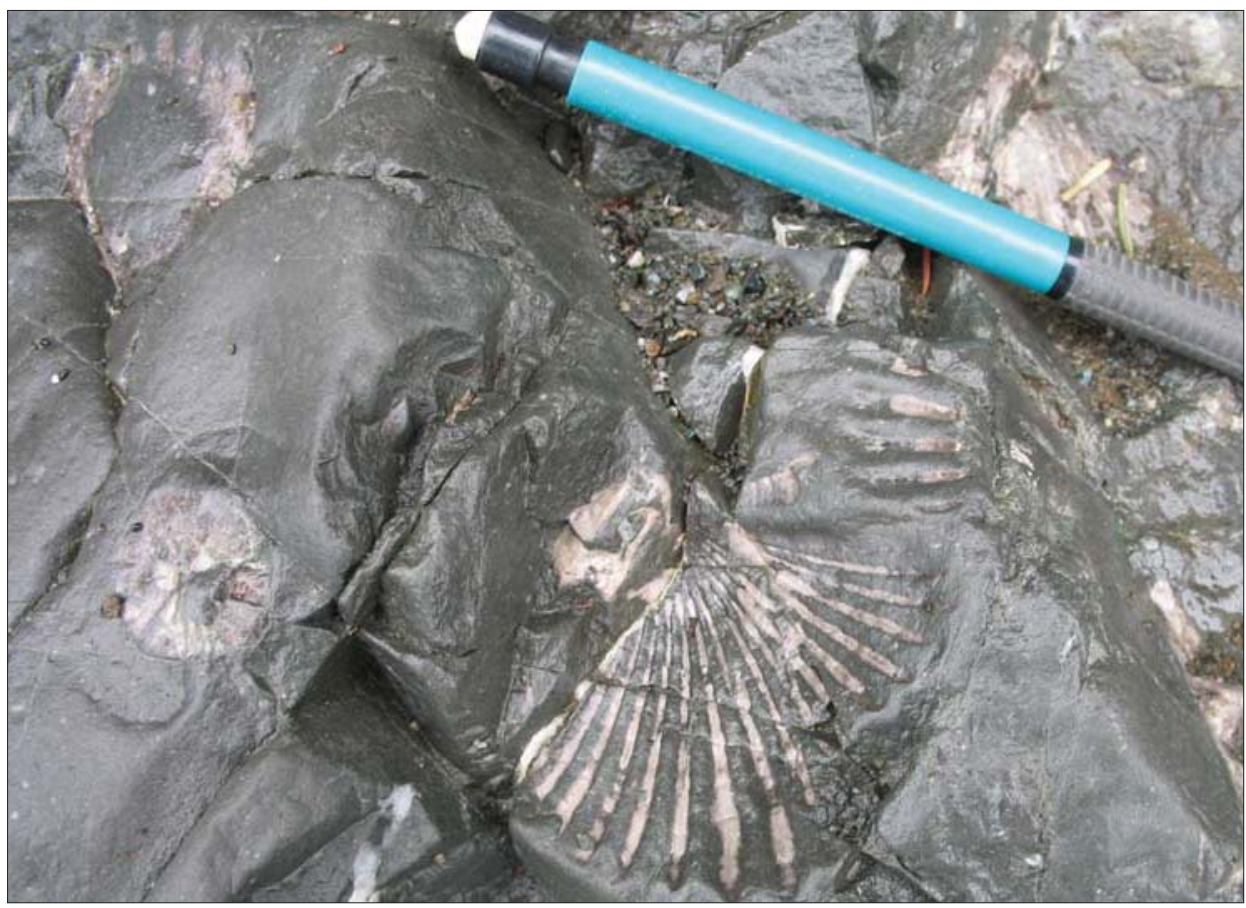

Figure 6. Bedding surface close to locality 07RB02 showing the large bivalve Weyla (probably Weyla alata). The rounded object near the left-center is a solitary scleractinian coral (note septa).

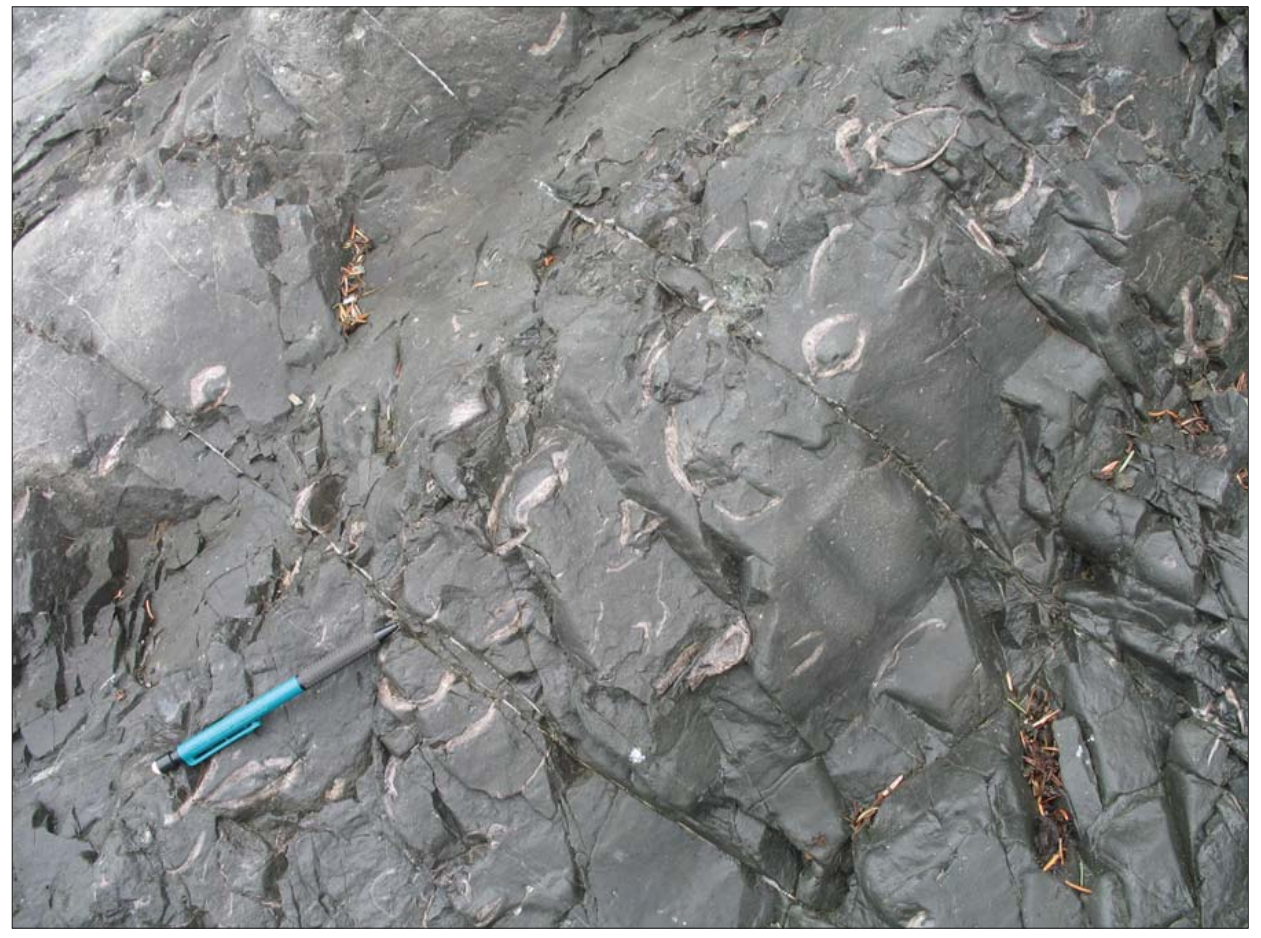

Figure 7. Bank of thick-shelled Weyla specimens between localities 07RB02 and 07RB3. Note that both articulated and disarticulated shells are present. 


\section{RB03}

Lat. $59.44381^{\circ} \mathrm{N}$, Long. $151.78600^{\circ} \mathrm{W}$

Fossils of abundant Weyla found higher in section (above 07RB02). Weyla is by far the most abundant fossil at this locality (fig. 8) as well as throughout the examined section. Occurs in mass accumulations, but also a few large snails observed, and several scattered solitary colonial corals (represented by at least two species). Most beds have horizontal bounding surfaces and are internally massive, but some cross-bedding is present lower in the section. Solitary corals present (figs. 9-11), but one would need a heavy hammer and sledge to recover them. Sands here are coarse grained and appear similar to equivalent age sands seen in the Lower Jurassic section at Puale Bay.

Most of the Weyla occurrences are in monotaxic banks (figs. 6-7), typically in sandstones and siltstone, often articulated, but some specimens are also disarticulated.

The rocks seen at these last two exposures much less altered than those seen in the Upper Triassic at 07RB1.

\section{ACKNOWLEDGMENTS}

I gratefully acknowledge support from DGGS to visit outcrops in the Port Graham area and Dave LePain for reviewing a draft of this manuscript.

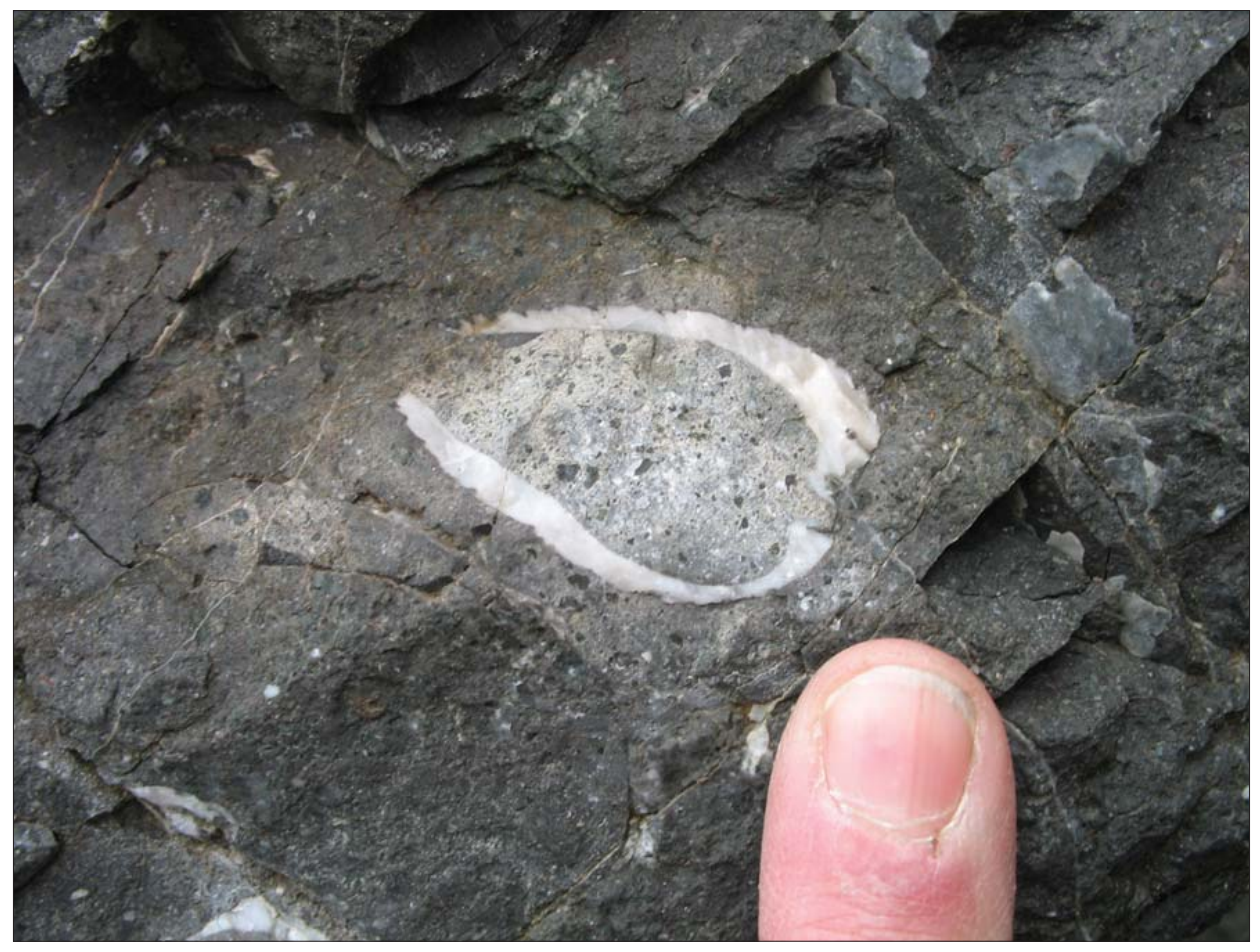

Figure 8. Cross-section of an articulated specimen of Weyla near locality 07RB03. Note angular grain shapes indicative of transport over relatively short distances from source to depositional site. 


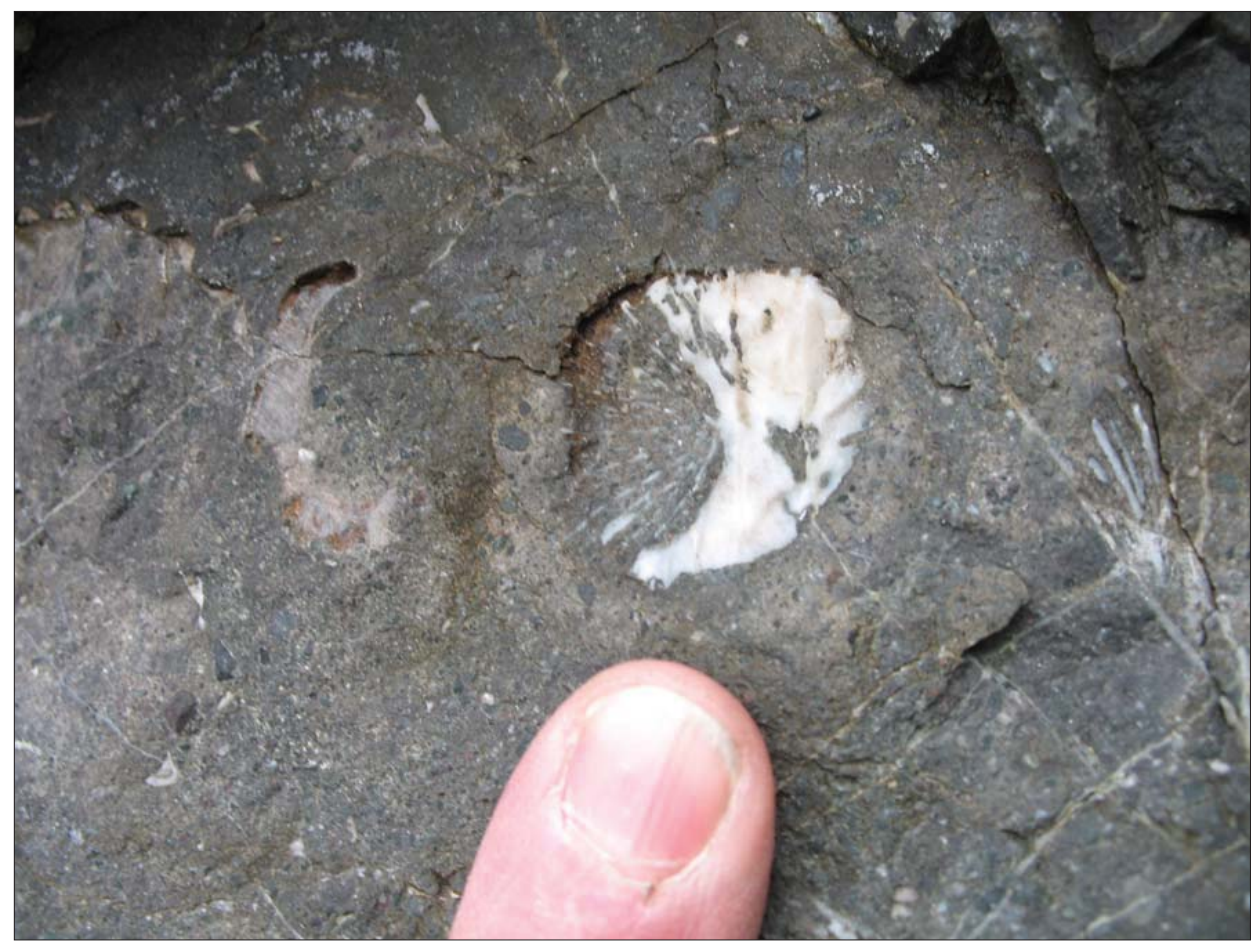

Figure 9. Solitary scleractinian coral in cross-section (note septa). Specimen found just below locality $07 R B 03$.

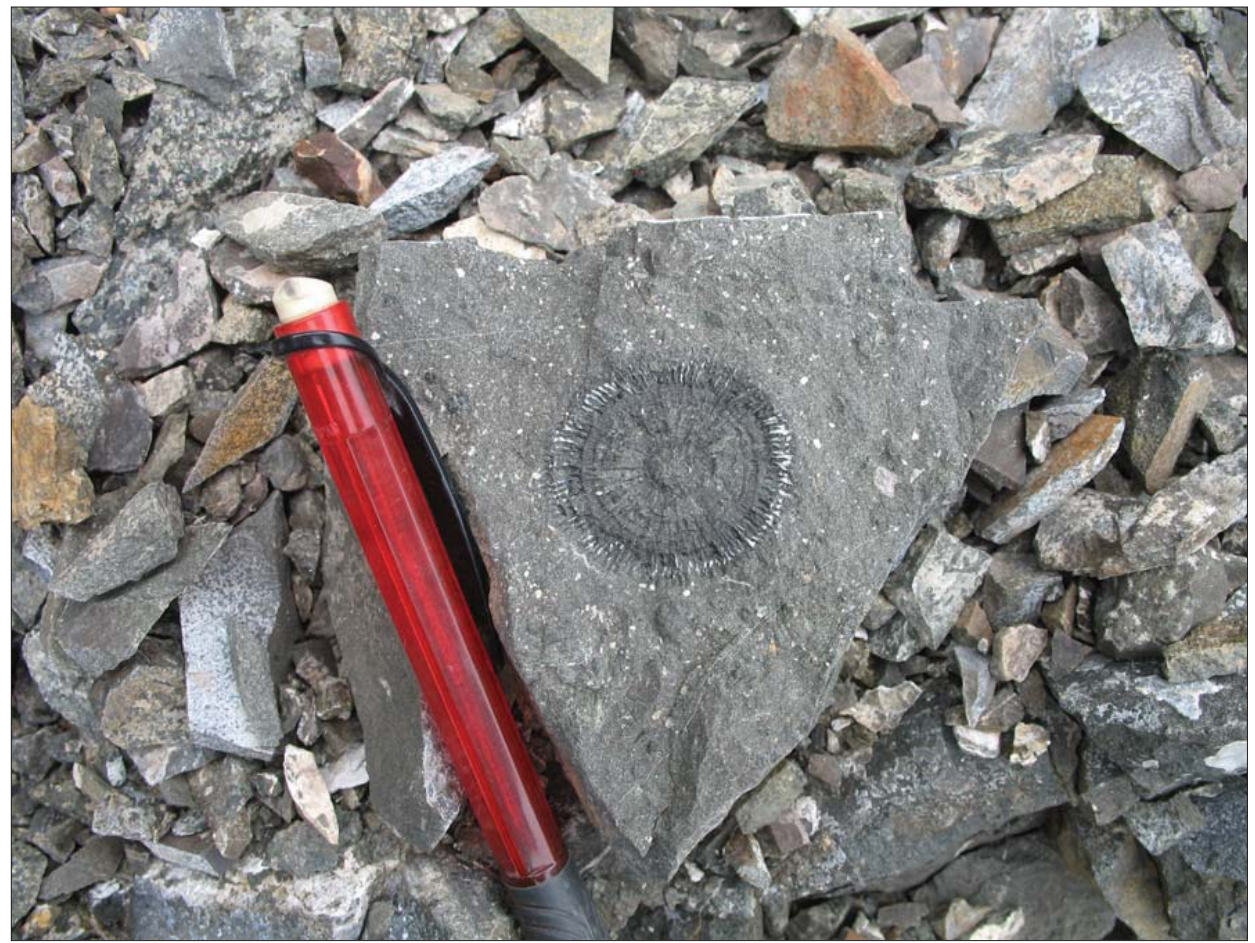

Figure 10. Base of discoidal solitary scleractinian coral from locality 07RB03. Reverse side of sample has numerous impressions of the bivalve Weyla. 


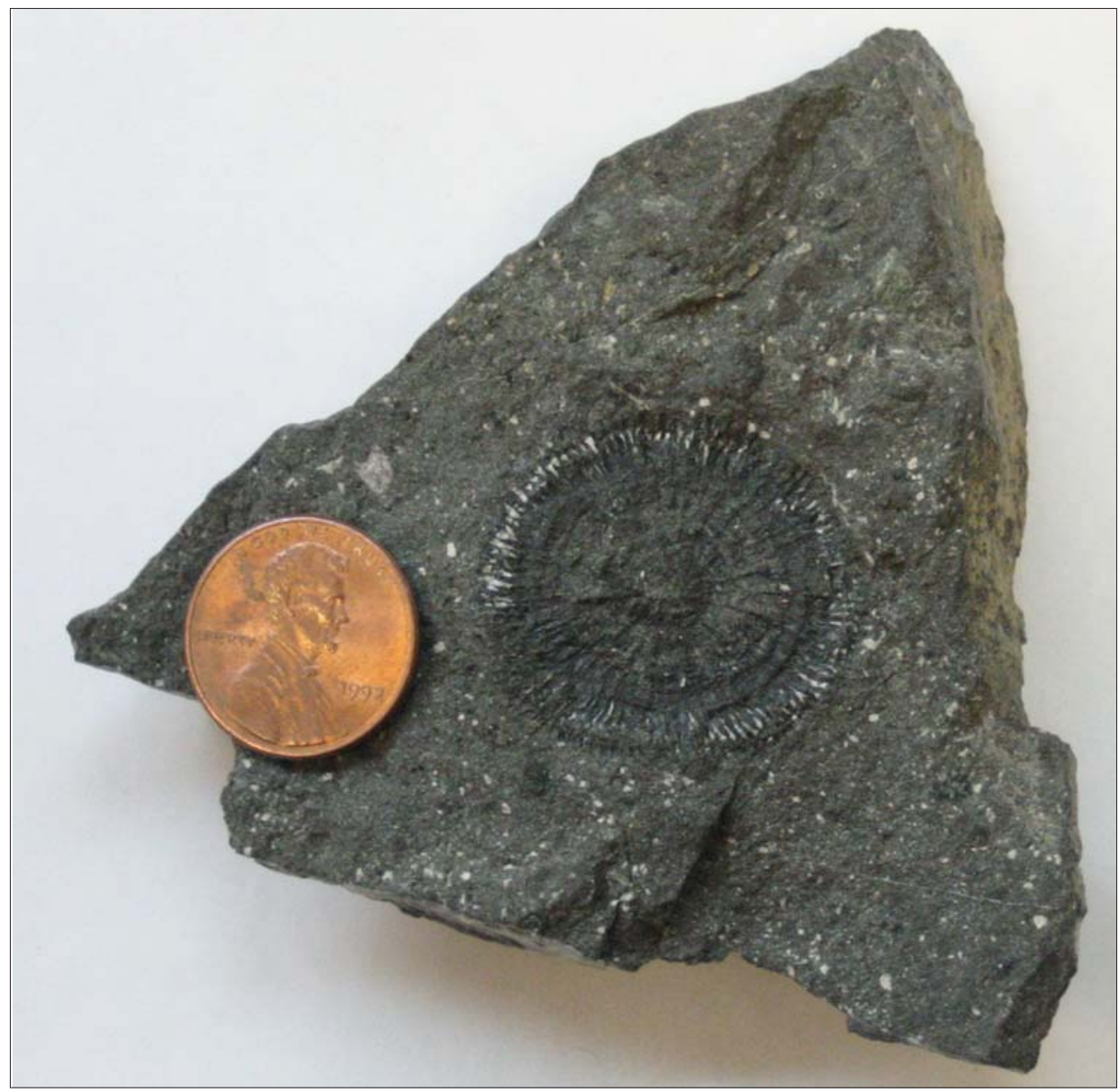

Figure 11. Same solitary scleractinian coral specimen as in fig. 10 (view taken inside under poor lighting)

\section{REFERENCES}

Bradley, D.C., Kusky, T.M., Haeussler, P.J., Karl, S.M., and Donley, D.T., 1999, Geologic map of the Seldovia quadrangle, south-central Alaska: U.S. Geological Survey Open-File Report 99-18, 1 sheet, scale 1:250,000.

Imlay, R.W., 1981, Early Jurassic ammonites from Alaska: U.S. Geological Survey Professional Paper 1148, 49 p., 12 pls.

Kelley, J.S., 1980, Environment of deposition and petrography of Lower Jurassic volcaniclastic rocks, southwestern Kenai Peninsula: Davis, California, University of California, Davis, Ph.D. dissertation, 304 p.

1984, Geologic map and sections of the southwestern Kenai Peninsula west of Port Graham, Alaska: U.S. Geological Survey Open-File Report 84-162, 1 sheet, scale 1:63,360.

Magoon, L.B., Adkison, W.L., and Egbert, R.M., 1976, Map showing geology, wildcat wells, Tertiary plant fossil localities, K-Ar age dates and petroleum operations, Cook Inlet area, Alaska: U.S. Geological Survey Map I-1019, 1 sheet, scale 1:250,000.

Martin, G.C., 1915, The western part of Kenai Peninsula: U.S. Geological Survey Bulletin 587, p. 41-112. 1926, The Mesozoic stratigraphy of Alaska: U.S. Geological Survey Bulletin 776, 493 p.

Silberling, N.A., Grant-Mackie, J.A., and Nichols, K.M., 1997, The Late Triassic bivalve Monotis in accreted terranes of Alaska: U.S. Geological Survey Bulletin 2151, 21 p., 11 pl.

Wilson, F.H., and Hults, C.P., 2008, Geology of the Prince William Sound and Kenai Peninsula region, Alaska: U.S. Geological Survey Open-File Report 2008-1002, 1 sheet, scale 1:350,000. 